\author{
Journal of Food Technology Research \\ 2021 Vol. 8, No. 2, pp. 50-57. \\ $\operatorname{ISSN}(e): 2312-3796$ \\ $\operatorname{ISSN}(p): 2312-6426$ \\ DOI: $10.18488 /$ journal.58.2021.82.50.57 \\ (C) 2021 Conscientia Beam. All Rights Reserved. \\ check for
updates
}

\title{
PREPARATION AND QUALITY EVALUATION OF Thekua INCORPORATED WITH GERMINATED FINGER MILLET (Ragi) FLOUR
}

\author{
Anish Dangal ${ }^{1+}$ \\ Anish Dhakal ${ }^{2}$ \\ Rajesh Shah ${ }^{3}$ \\ Diksha Timsina ${ }^{4}$ \\ Sangam Dahal ${ }^{5}$
}

\author{
${ }^{1,2,3,4}$ Nilgiri College, Tribhuvan University, Itahari, Nepal. \\ 'Email: anishdangal42@gmail.com Tel: +9779862341886 \\ ${ }^{2}$ Email: anishdhakal2053@gmail.com Tel: +9779866547522 \\ ${ }^{3}$ Email: rajeshshah.dharan@gmail.com Tel: +9779852032300 \\ ${ }^{4}$ Email: dikxutimsina@gmail.com Tel: +9779819364002 \\ ${ }^{5}$ Central Department of Food Technology, Tribhuvan University, Dharan, \\ Nepal. \\ ${ }^{5}$ Email: mymail2mrsngam@gmail.com Tel: +9779811046561
}

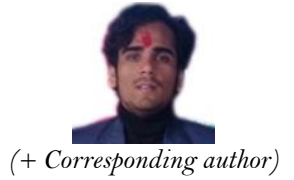

ABSTRACT
Article History

Received: 22 October 2021 Revised: 25 November 2021 Accepted: 14 December 2021 Published: 27 December 2021

Keywords

Finger millet ( ragi)

Thekua

Nutritional compositions

Minerals

Anti-nutritional factor

Sensory evaluation.
The main aim of this study was to prepare thekua with the incorporation of germinated finger millet also known as ragi, flour and to perform its sensory as well as physicochemical analysis. The wheat flour and finger millet (ragi) flour were mixed with variation at the proportion of 87.5:12.5, 81.25:18.75, 100:0, 75:25 and 93.75:6.25 labeled as samples A, B, C, D and E respectively., while semolina (20 g), sugar (30 g), oil (20 g) and water (20 g) were kept constant for every formulation. The FFA and acid value of the oil used was found to be $0.110 \pm 0.02$ and $0.221 \pm 0.03$ respectively. The moisture content of sugar used was found to be 0.16 \pm 0.01 . Sample 'E' was considered best as per the acceptability by panelists and had crude fiber (\%), calcium content $(\mathrm{mg} / \mathrm{loog})$, tannin $(\mathrm{mg} / \mathrm{loog})$, phytate $(\mathrm{mg} / \mathrm{logg})$, carbohydrate and total energy (Kcal/100g) of $0.24 \pm 0.01,18.6 \pm 0.02,27.03 \pm 0.86,135.97 \pm 1.15,64.42 \pm 0.04$ and $512.41 \pm 0.07$ respectively. Increase in fiber content and minerals was seen in best sample product with the incorporation of germinated finger millet ( ragi) flour.

Contribution/Originality: This study follows methodology from various authors especially (Ranganna, 2007). Very few researches have been performed in thekua, the traditional food of Nepal. So the formulation prepared is unique. The nutritional value of thekua which was initially only a source of energy is improved by the use of germinated finger flour.

\section{INTRODUCTION}

In Nepal there is people habitation of various cast, religions, ethnicity etc. with different cultures. Nepalese cuisine comprises a spread of cuisines based upon ethnicity, soil and climate regarding Nepal's cultural diversity and geography. The origin history of traditional foods is untraceable so it's still unknown to us. Every grouping has their own values, norms and believes. Traditional foods are directly associated with the norms and beliefs of a selected grouping (Dangal, 2019). Traditional foods reflect cultural heritage and have left their marks on modern dietary habits, they're key elements of dietary habits in numerous countries and are therefore important for estimating population dietary intakes accurately (Trichopoulou, Soukara, \& Vasilopoulou, 2007). Traditional foods are about choosing the simplest food options available for your budget, individual chemistry \& location (Dangal, 2019). Thekua; the normal food which is a sweet product with less nutrient contents, is indigenous to Maithili communities of terai region of Nepal and is typically utilized in several occasions, festivals, rituals, offerings and as 
special foods on big day; especially on the occasion of Chhat festival. Its deep-fried product viewed as a precursor of western biscuits prepared by mixing of white flour, sugar, ghee and few spices (Suman, 2012).

Finger millet $\left(\mathrm{rag}_{\mathrm{l}}\right)$ is originally native to the Ethiopian Highlands and was introduced into India about 4000 years ago. It's a significant crop in India, Nepal and adaptable to higher elevations, ragi is grown in the Himalaya up to 2,300 meters in elevation. The peak harvesting time of finger millet is December-January. Finger millet is valuable since it contains the amino acid methionine, which is lacking in the diets of hundreds of millions of the poor who live on starchy staples such as cassava, plantain, polished rice or maize meal (Peterson, 1974). The topography and soil make-up at various locations of Nepal has been suitable to cultivate finger millet and therefore the crop has occupied second position in hills, next to maize. It's equally grown in inner terai region of Nepal, especially in unirrigated land (Dawadi, 1999).

\section{MATERIALS AND METHODS}

\subsection{Collection of Raw Materials}

Finger millet was bought from the local markets of Letang $\left(26.7509^{\circ} \mathrm{N}, 87.4802^{\circ} \mathrm{E}\right)$. Sugar, semolina, wheat flour and refined sunflower oil were bought from the local market of Itahari $\left(26.7509^{\circ} \mathrm{N}, 87.4802^{\circ} \mathrm{E}\right)$.

\subsection{Preparation of thekua}

Thekua was prepared as that of Sah (2019) with slight modifications Figure 1. Finger millet was germinated before being grounded into flour and the flour was used with white wheat flour to make thekua. Semolina (20 g), sugar (30 g), oil (20 g) and water (20 g) were kept constant for every formulation Table 1.

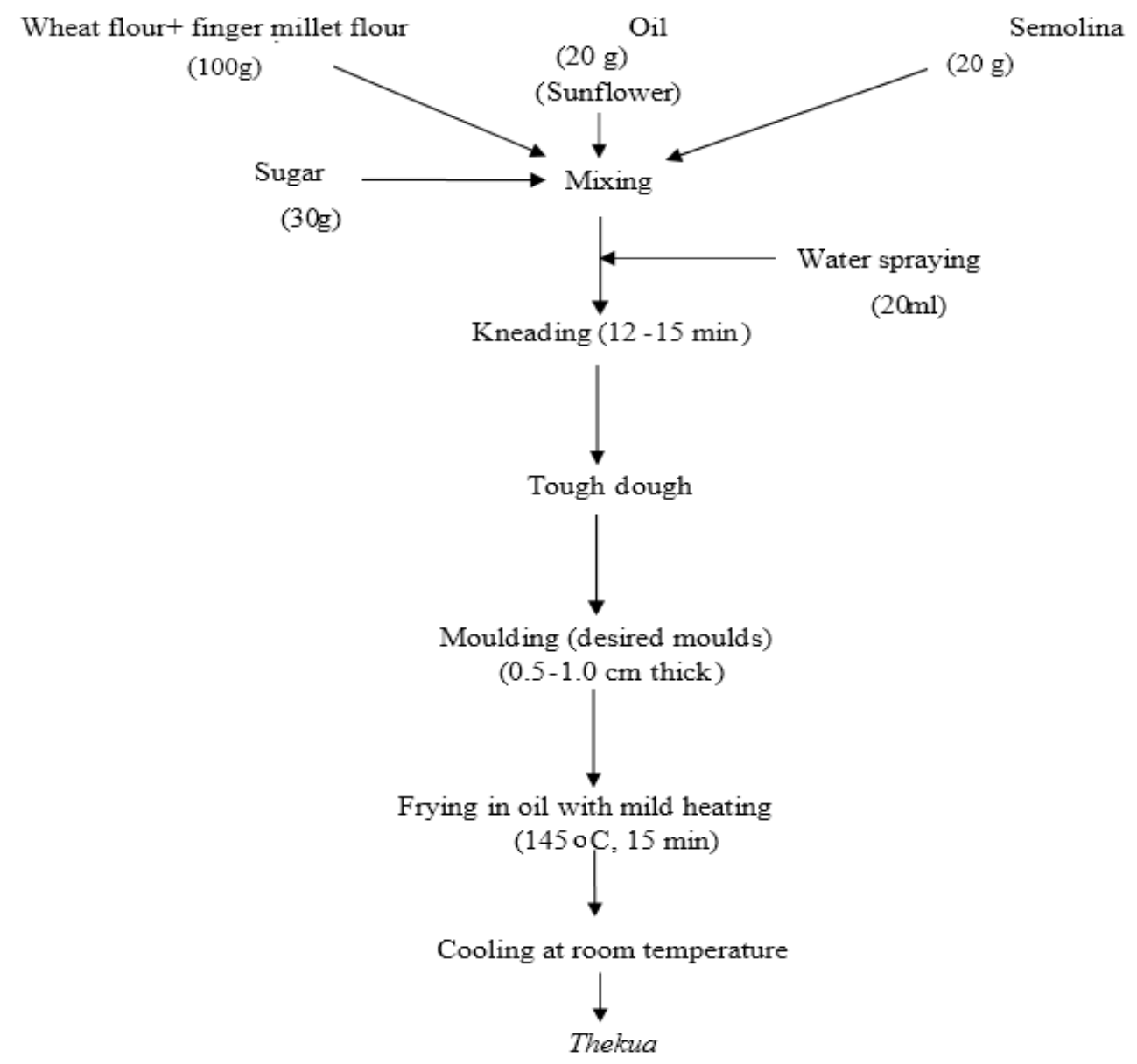

Figure-1. Preparation process of thekua. 
Table-1 Coding of the samples with different proportions of wheat flour and germinated finger millet ( ragi) flour.

\begin{tabular}{c|c|c}
\hline Sample & Wheat flour $(\mathbf{g})$ & Finger millet (ragi) flour (g) \\
\hline $\mathrm{A}$ & 100 & $\mathrm{O}$ \\
\hline $\mathrm{B}$ & 81.25 & 18.75 \\
\hline $\mathrm{C}$ & 87.5 & 12.5 \\
\hline $\mathrm{D}$ & 75 & 25 \\
\hline $\mathrm{E}$ & 93.75 & 6.25 \\
\hline Note: * Semolina $(20 \mathrm{~g})$, sugar $(30 \mathrm{~g})$, oil $(20 \mathrm{~g})$ and water $(20 \mathrm{~g})$ were kept constant for every formulation.
\end{tabular}

\subsection{Proximate and Chemical Analysis}

Moisture, crude fat, crude protein, total ash, crude fiber and calcium content of samples were determined as per described by Ranganna (2007) while carbohydrate content was estimated by difference. Energy value was expressed as Kcal/100g and was calculated by multiplying the values of crude protein, lipids and carbohydrates by recommended factors (4, 9 and 4 respectively) (Valdez-Solana et al., 2015). Gluten, free fatty acid and acid value were determined as per described by KC and Rai (2007).

\subsection{Determination of Phytic Acid}

The phytic acid was extracted with trichloroacetic acid and precipitated as ferric salt. The iron content of the precipitate was determined colorimetrically and the phytate phosphorous content calculated from this value assuming a constant 4 Fe: 6 P molecular ratios in the precipitate, as described in Sadasivam and Manickam (1991). The mg iron present in $\mathrm{Fe}\left(\mathrm{NO}_{3}\right)_{3}$ was calibrated from the standard curve. And the phytate content determined on the basis of following relation:

$1 \mathrm{mg}$ iron $=0.8321 \mathrm{mg}$ phytate.

\subsection{Determination of Tannin}

Tannin was determined by Folin-Denis method as described by Sadasivam and Manickam (1991). $1 \mathrm{~g}$ ground millet sample with $50 \mathrm{ml}$ distilled water was boiled for 30 minutes, the solution was cooled and volume made up to $100 \mathrm{ml}$. Then the solution prepared was filtered through filter paper (Whatman no.1). One ml of the filtrate was taken in which $0.5 \mathrm{ml}$ Folin-Denis reagent was added, then $1 \mathrm{ml}$ of sodium carbonate was added and volume made up to $10 \mathrm{ml}$. Then the prepared solution was left at room temperature for 30 minutes and then the absorbance was read at 760nm against a reagent blank. The tannin content in millet samples were calculated as tannic acid equivalent from the standard graph and value determined from the following equation:

1 O.D. (Optical Density) $=0.1931 \mathrm{mg}$

\subsection{Sensory Evaluation}

Ten panelists evaluated the samples of thekua by using 9-point hedonic rating test (9-like extremely, 8- like very much, 7- like moderately, 6- like slightly, 5- neither like nor dislike, 4- dislike slightly, 3- dislike moderately, 2- dislike very much, and 1- dislike extremely) Ranganna (2007). The panelists were provided with the uniform quantity of thekua in stainless steel plate to analyze color, texture, taste, smell, appearance and overall acceptability.

\subsection{Statistical Analysis}

The data of each experimental analysis that were performed in triplicate was analyzed by one- way analysis of variance (ANOVA) by using software GenStat Release 12.1 (Copyright 2009, VSN International Ltd.). MS-Excel 2019 was used for charts and curves. Means were separated using Tukey’s HSD post hoc test $(\mathrm{P}<0.05)$. 


\section{RESULTS AND DISCUSSION}

\subsection{Nutritional and Chemical Composition of Wheat Flour}

Proximate composition and chemical composition of wheat flour is presented in Table 2. The crude protein content of wheat flour (10.2\%) was lower than that obtained by Sarwar (2010) and Khanal (1997). The crude fiber and total ash content were little lower than obtained by Khanal (1997) but crude fat was found to be greater than that of Sarwar (2010) and Khanal (1997). The difference in proximate composition may be due to factors like varieties, climatic conditions, soil type, maturity, fertility and others.

Table-2. Quantitative analysis of physico-chemical properties of wheat flour.

\begin{tabular}{l|l}
\hline Parameters & Results \\
\hline Moisture content (\%) & $12.92 \pm 0.01$ \\
\hline Crude protein (\%) & $10.2 \pm 0.01$ \\
\hline Crude fat (\%) & $1.09 \pm 0.02$ \\
\hline Crude fiber (\%) & $0.4 \pm 0.02$ \\
\hline Total ash content (\%) & $0.38 \pm 0.01$ \\
\hline Total carbohydrate (\%) & $75.01 \pm 0.03$ \\
\hline Gluten (\%) & $9.29 \pm 0.02$ \\
Calcium content (mg/100 g) & $19.98 \pm 0.03$ \\
\hline Total energy (Kcal) & $350.65 \pm 0.1$ \\
\hline Note: Values are means of triplicate \pm standard deviations.
\end{tabular}

\subsection{Nutritional and Chemical Composition of Germinated Finger Millet (ragi) Flour}

Proximate composition and chemical composition germinated finger millet ( ragi) flour is presented in Table 3. The moisture content (\%), crude protein (\%), crude fat (\%), crude fiber (\%), total ash content (\%), tannin (mg/10og), phytate (mg/100g), carbohydrate (\%) and total energy (Kcal) of germinated finger millet flour was found to be $10.11,9.58,1.01,2.98,2.53,205.13,350.08,73.78$ and 342.62 respectively. Finger millet grain has low fat content probably because it has a relatively smaller germ (Serna-Saldivar \& Rooney, 1995). Malting significantly decreases the carbohydrate, fat content and improves ash content of finger millet (Akubor \& Obiegbuna, 1999). antinutritional factors of ragi like phytic acid and tannins have their own health benefits. Dietary phytate was reported to prevent kidney stone formation (Grases et al., 2000), protect against diabetes mellitus (Thompson, 1993), caries (Kaufman \& Kleinberg, 1971), atherosclerosis and coronary heart disease (Jariwalla, Sabin, Lawson, \& Herman, 1990) as well as against a variety of cancers (Vucenik \& Shamsuddin, 2003). Tannins exhibit antioxidant and anti-fungal properties (Siwela, 2009). Hence, completely eliminating the phytic acid and tannins from finger millet won't be beneficial.

Table-3. Quantitative analysis of physiochemical properties of germinated finger millet (ragi) flour.

\begin{tabular}{l|l}
\hline Parameters & Results \\
\hline Moisture content $(\%)$ & $10.11 \pm 0.02$ \\
\hline Crude protein $(\%)$ & $9.58 \pm 0.03$ \\
\hline Crude fat $(\%)$ & $1.01 \pm 0.01$ \\
\hline Crude fiber $(\%)$ & $2.98 \pm 0.01$ \\
\hline Tannin $(\mathrm{mg} / 100 \mathrm{~g})$ & 205.13 \\
\hline Phytate $(\mathrm{mg} / 100 \mathrm{~g})$ & 350.08 \\
\hline Total ash content $(\%)$ & $2.53 \pm 0.01$ \\
\hline Total carbohydrate $(\%)$ & $73.78 \pm 0.02$ \\
\hline Total energy & $342.62 \pm 0.13$ \\
\hline
\end{tabular}

Note: Values are means of triplicate \pm standard deviations.

\subsection{Nutritional Analysis of thekua}

Proximate composition and chemical composition germinated finger millet (ragi) flour is presented in Table 4. Crude protein, crude fat, crude fiber, total carbohydrate and total energy of the control sample 'A' was found to be lower but total ash content was found to be greater than that obtained by Sah (2019). The moisture content (\%), 
total ash content (\%), crude protein (\%), crude fat (\%), crude fiber (\%), calcium content (mg/100g), tannin (mg/100g), phytic acid (mg/100g), carbohydrate (\%) and total energy (Kcal/100g) of best sample 'E' was found to be $4.16 \pm 0.01,0.50 \pm 0.02,4.98 \pm 0.01,26.09 \pm 0.03,0.24 \pm 0.01,18.6 \pm 0.02,27.03 \pm 0.86,135.97 \pm 1.15,64.42 \pm 0.04$ and $512.41 \pm 0.07$ respectively. The phytic acid content can also be reduced during baking or frying (Faqir, Butt, Ahmad, \& Ahmad, 2002).

There was increase in calcium content and crude fiber due to the addition of germinated finger millet flour. The increase of total ash content and total carbohydrate was also obtained in the final best product sample E. The best product was found to be comparatively low in energy than control sample A.

Table-4. Quantitative analysis of physico-chemical properties of thekua.

\begin{tabular}{|c|c|c|}
\hline Parameters & Control sample (A) & Best sample (E) \\
\hline Moisture content (\%) & $4.12 \pm 0.01$ & $4.16 \pm 0.01$ \\
\hline Crude protein $(\%)$ & $6.89 \pm 0.02$ & $4.98 \pm 0.01$ \\
\hline Crude fat $(\%)$ & $27.05 \pm 0.01$ & $26.09 \pm 0.03$ \\
\hline Crude fiber (\%) & $0.15 \pm 0.01$ & $0.24 \pm 0.01$ \\
\hline Total ash content (\%) & $0.39 \pm 0.01$ & $0.50 \pm 0.02$ \\
\hline Calcium content (mg per $100 \mathrm{~g}$ ) & $14.02 \pm 0.01$ & $18.6 \pm 0.02$ \\
\hline Total carbohydrate (\%) & $61.40 \pm 0.04$ & $64.42 \pm 0.04$ \\
\hline Tannin $(\mathrm{mg} / 100 \mathrm{~g})$ & $18.98 \pm 2.28$ & $27.03 \pm 0.86$ \\
\hline Phytate (mg/100g) & $115.09 \pm 1.001$ & $135.97 \pm 1.15$ \\
\hline Total energy (Kcal) & $516.61 \pm 0.01$ & $512.41 \pm 0.07$ \\
\hline
\end{tabular}

\subsection{Sensory Analysis of thekua}

The sample products were subjected to sensory analysis Figure 2. Statistical analysis showed that there is significant effect $(\mathrm{p}<0.05)$ on the sensory parameters of the samples at $5 \%$ level of significance. Among the product samples, after control sample A, sample E got the highest score and this was the best in terms of sensory attributes.

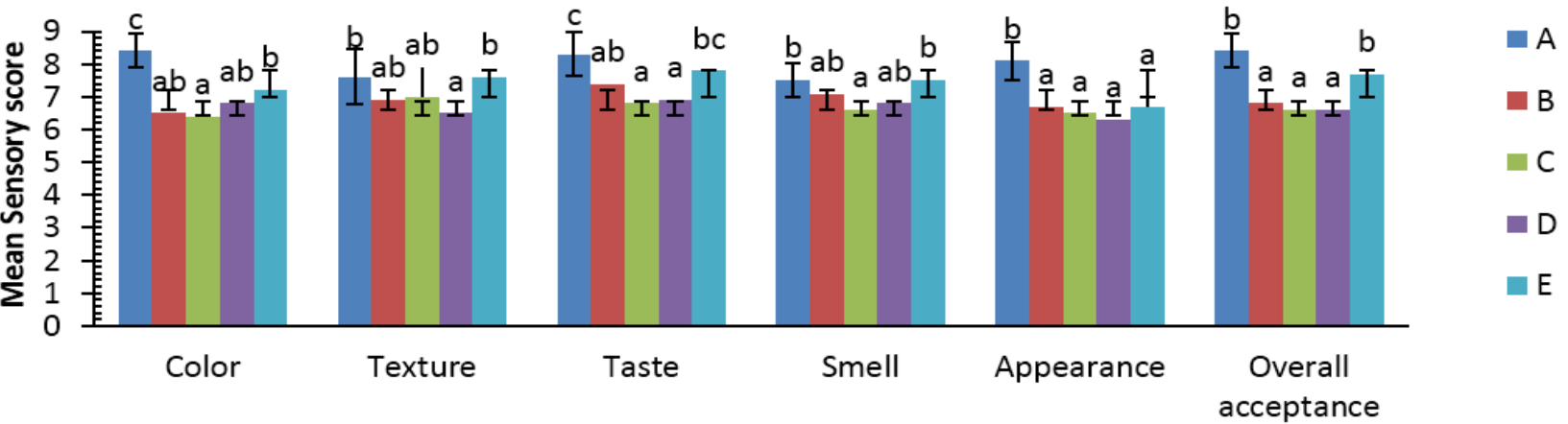

Figure-2. Sensory analysis of the different samples of thekua. Error bars show standard deviation and error bars bearing different superscript differs $(\mathrm{P}<0.05)$.

\subsection{Shelf-Life Evaluation of Germinated Finger Millet (ragi) Flour Incorporated Thekua}

The best product sample 'E' was packed in low density poly-ethylene (LDPE) plastic packets and stored at normal room condition. Moisture content, free fatty acid and acid value in laboratory upto 1 month in an interval of 7 days Figure 3, 4 and 5. For the analysis of free fatty acid and acid value, oil extraction of thekua was done and the oil was kept for further analysis upto 1 month. The values were below the unacceptability level of maximum as described by Mukhopadhyay (1990) till the last date of analysis. The rate of increase in moisture content (\%), free fatty acid (\% as oleic acid) and acid value $(\mathrm{mg} \mathrm{KOH} / \mathrm{g}$ oil) of best product sample ' $\mathrm{E}$ ' with respect to shelf-life analysis was found to be $0.0125,0.00076$ and 0.0015 respectively. These rates may accelerate after storage period of 
30 days. The rate of increase of acid value, moisture content and free fatty acid can be decreased with the use of better packaging materials, better storage condition and by use of antioxidants and preservatives.

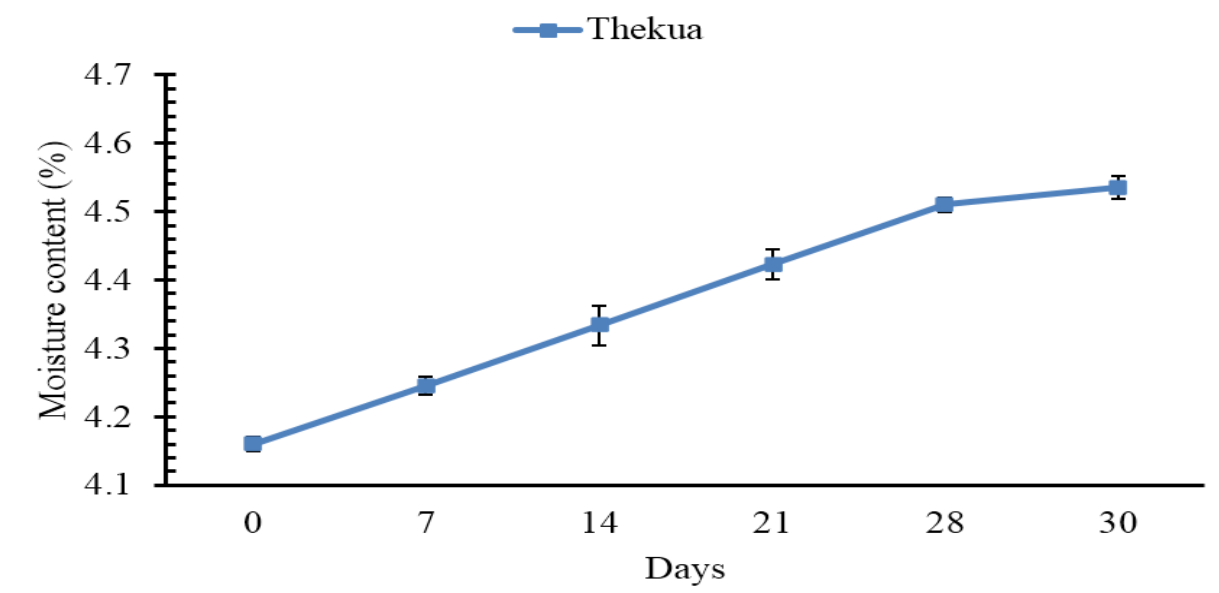

Figure-3. Changes in moisture content of thekua with respect to days.

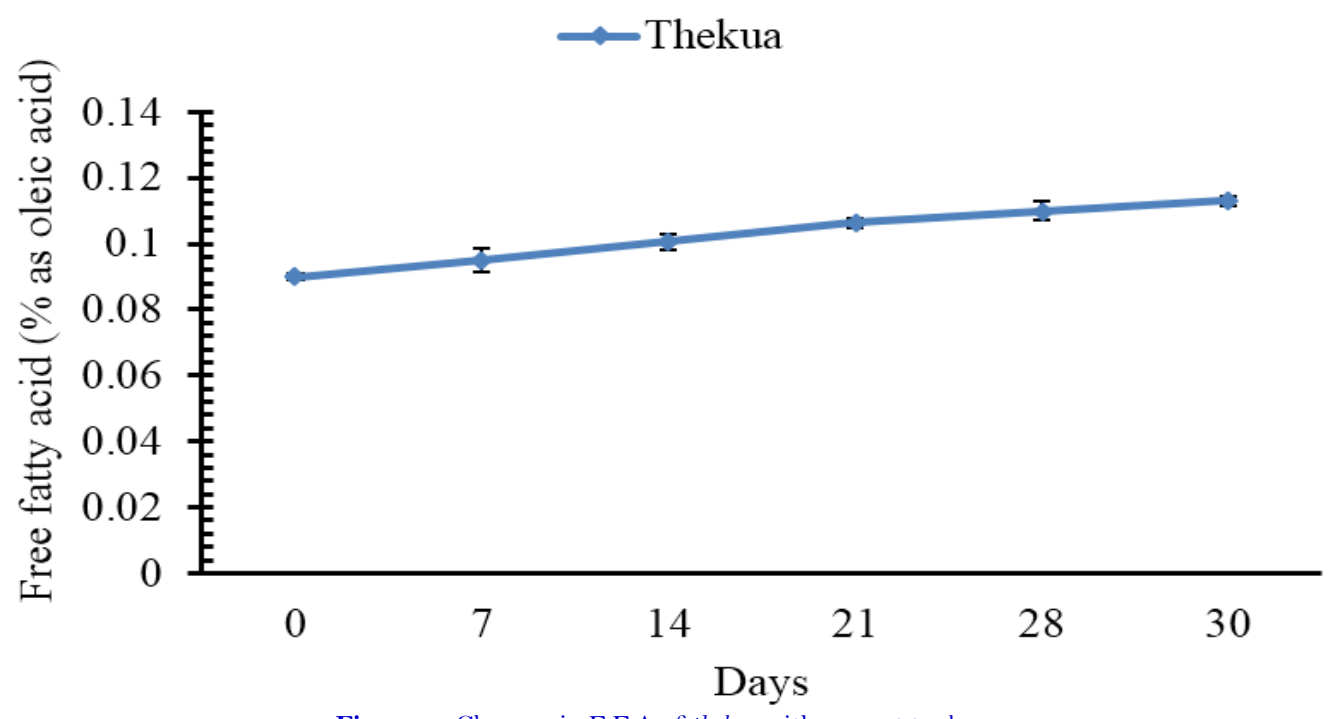

Figure-4. Changes in F.F.A of thekua with respect to days.
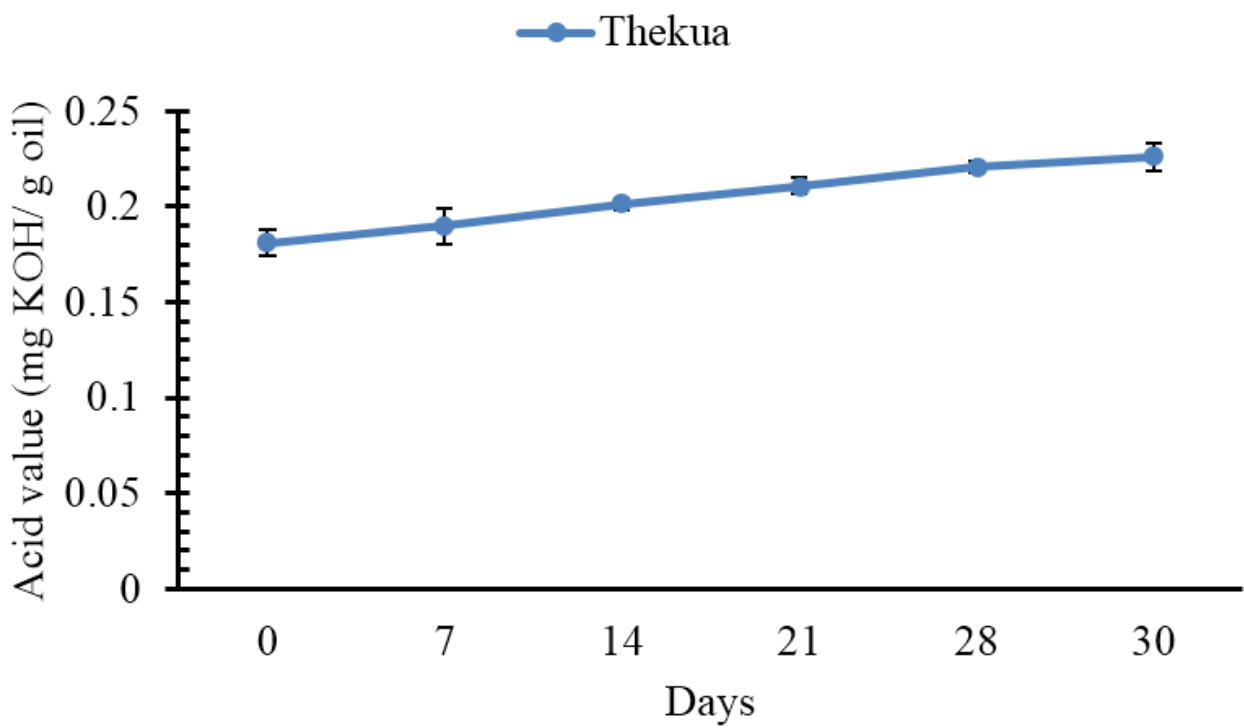

Figure-5. Changes in acid value of thekua with respect to days. 


\subsection{Cost Evaluation}

The cost of $100 \mathrm{~g}$ of thekua was calculated as NRs. 15.38, considering $25 \%$ overhead expenses. Cost can be reduced by mass production.

\section{CONCLUSION}

Thekua should be exclusively innovated to fix the micro and macro-nutrient deficiency of cultural and indigenous food that fits the Nepalese diet diversity. In addition, it can be produced as functional food that could enhance people's nutritional status and increase the utilization of under-utilized crop like finger millet ( rag $\imath$ ) of our country. Thekua prepared from 93.75 parts wheat flour and 6.25 parts germinated finger millet flour was found to be superior in consumer acceptance compared to other samples. Most of the sensory characteristics and nutritional characteristics of control sample 'A' and best sample 'E' were significantly different $(\mathrm{p}<0.05)$.

Funding: This study received no specific financial support.

Competing Interests: The authors declare that they have no competing interests.

Acknowledgement: All authors contributed equally to the conception and design of the study.

\section{REFERENCES}

Akubor, P., \& Obiegbuna, J. (1999). Certain chemical and functional properties of ungerminated and germinated millet flour. Journal of Food Science and Technology (Mysore), 36(3), 241-243. Available at: https://doi.org/10.11648/j.ijnfs.20150402.18.

Dangal, A. (2019). Cereal based unfermented traditional foods of nepal and its importance [College Report]: Nilgiri College, Nepal.

Dawadi, G. (1999). Processing of Ragi and its utilization in Biscuits. Research work. India: CFTRI, Mysore-570013.

Faqir, A. M., Butt, M. S., Ahmad, N., \& Ahmad, I. (2002). Phytate and mineral content in different milling fractions of some Pakistani spring wheats. International Journal of Food Science \& Technology, 37(1), 13-17. Available at: https://doi.org/10.1046/j.1365-2621.2002.00540.x.

Grases, F., March, J., Prieto, R., Simonet, B., Costa-Bauzá, A., García-Raja, A., \& Conte, A. (2000). Urinary phytate in calcium oxalate stone formers and healthy people: dietary effects on phytate excretion. Scandinavian Journal of Urology and Nephrology, 34(3), 162-164. Available at: https://doi.org/10.1080/003655900750016526.

Jariwalla, R., Sabin, R., Lawson, S., \& Herman, Z. (1990). Lowering of serum cholesterol and triglycerides and modulation of divalent cations by dietary phytate. Journal of Applied Nutrition, 42(1), 18-28.

Kaufman, H., \& Kleinberg, I. (1971). Effect of pH on calcium binding by phytic acid and its inositol phosphoric acid derivatives and on the solubility of their calcium salts. Archives of Oral Biology, 16(4), 445-460. Available at: https://doi.org/10.1016/0003-9969(71)90168-3.

KC, J. B., \& Rai, B. K. (2007). Basicfood analysis handbook (1st ed.). Anamnagar, Kathmandu, Nepal: Prompt Printers Pvt. Ltd.

Khanal, T. R. (1997). Preparation of bread using wheat malt flour. Bachelor of Food Technology Thesis, Tribhuvan University Nepal.

Mukhopadhyay, M. (1990). A seminar paper on process of manufacturing quality biscuits and new product development. Calcutta: Britannia Industries Limited.

Peterson, J. (1974). Encyclopedia offood technology (Vol. 2). Westport, Connecticut: The AVI Publishing Company, INC.

Ranganna, S. (2007). Handbook of analysis and quality control for fruit and vegetable products (2nd ed.). New Delhi: Tata McGraw Hill Pub. Co. Ltd.

Sadasivam, S., \& Manickam, A. (1991). In: Biochemical methods for agricultural sciences (pp. 5-201). New Delhi: Wiley Eastern Limited.

Sah, S. (2019). Preparation and quality evaluation of sahjiwan (Moringa Oleifera) Incorporated Khajuri. Thesis Central Department of Food Technology. 
Sarwar, G. (2010). Preparation and quality evaluation of composite bread from wheat flour and finger millet (Elusine coracana L.) flour (malted and unmalted). Bachelor of Food Technology Thesis. Tribhuvan University, Dharan.

Serna-Saldivar, S., \& Rooney, L. W. (1995). Structure and chemistry of sorghum and millets. In: "Sorghum and Millets: Chemistry and Technology" (D.A.V. Dandy, ed). St Paul, MN: AACC International.

Siwela, M. (2009). Finger millet grain phenolics and their impact on malt and cookie quality. Ph.D. Thesis, University of Pretoria, South Africa.

Suman, A. (2012). Optimization of formulation and process for the preparation of Khajuri (A Maithili Indigenous Food). Thesis Central Department of Food Technology.

Thompson, L. U. (1993). Potential health benefits and problems associated with antinutrients in foods. Food Research International, 26(2), 131-149. Available at: https://doi.org/10.1016/0963-9969(93)90069-u.

Trichopoulou, A., Soukara, S., \& Vasilopoulou, E. (2007). Traditional foods: A science and society perspective. Trends in Food Science \& Technology, 18(8), 420-427.

Valdez-Solana, M. A., Mejia-Garcia, V. Y., Tellez-Valencia, A., Garcia-Arenas, G., Salas-Pacheco, J., Alba-Romero, J. J., \& SierraCampos, E. (2015). Nutritional content and elemental and phytochemical analyses of Moringa oleifera grown in Mexico. Journal of Chemistry.

Vucenik, I., \& Shamsuddin, A. M. (2003). Cancer inhibition by inositol hexaphosphate (IP6) and inositol: From laboratory to clinic. The Journal of Nutrition, 133(11), 3778S-3784S.

Views and opinions expressed in this article are the views and opinions of the author(s), Journal of Food Technology Research shall not be responsible or answerable for any loss, damage or liability etc. caused in relation to/arising out of the use of the content. 